\title{
Õpetajate-õpilaste interaktsioon ja sisuloome suhtlusportaalides: õpetajate arvamused ja kogemused
}

\author{
Sandra Räim ${ }^{\mathrm{a} 1}$, Andra Siibak ${ }^{\mathrm{a}}$ \\ a Tartu Ülikooli ühiskonnateaduste instituut
}

\begin{abstract}
Annotatsioon
Artikli eesmärk on anda ülevaade õpetajate arvamustest ja kogemustest, mis puudutavad õpetajate ja õpilaste interaktsiooni ja sisuloomet suhtlusportaalides. Fookusgrupi intervjuudes nelja kooli keskkooliõpetajatega $(N=21)$ uuriti, milliseid erinevusi on õpetajad täheldanud enda ja õpilaste loodud veebisisus ning millistel juhtudel ja mil viisil on õpetajad pidanud vajalikuks õpilaste suhtlusportaalide postitustele reageerida. Muu hulgas sooviti teada, millistele alustele tugineb õpetaja-õpilase suhtlusportaali sõprus ning kas õpetajad tunnevad vajadust sotsiaalmeedia suhtlust suunavate käitumisjuhiste järele. Intervjuude kvalitatiivsest sisuanalüüsist nähtub, et õpetajate arvates jagavad õpilased suhtlusportaalides liigselt privaatset infot, mistõttu pidasid nad enda kohuseks ebasobivaid postitusi märgates õpilaste sisuloomesse sekkuda. Õpetajad võtsid ka suhtlusportaalides endale õpilaste harija ja mentori rolli ning soovisid oma veebikäitumisega pakkuda eeskuju, samas ei adunud nad täiel määral õpetaja-õpilase veebisuhtluse võimalikke tagajärgi. Õpetaja-õpilase veebisuhtlust reguleerivate käitumisjuhiste järele aga vajadust ei nähtud. Uuringu tulemused viitavad veebisisu loomega kaasnevatele põlvkondlikele erinevustele ning avavad õpetajate-õpilaste probleeme suhtlusportaali auditooriumi tajumisel.
\end{abstract}

Võtmesõnad: suhtlusportaalid, õpetaja-õpilase sõprus suhtlusportaalides, privaatsus, põlvkondlikud erinevused, õpetaja roll

1 Ühiskonnateaduste instituut, sotsiaal- ja haridusteaduskond, Tartu Ülikool, Lossi 36, 51003 Tartu; sandra.raim@ut.ee 


\section{Sissejuhatus}

Tänapäevane tehnoloogia on tekitanud olukorra, kus piirid avaliku ja privaatse info vahel on hägustunud. Kui varem oli õpetaja ja õpilase suhtlus peaasjalikult professionaalne ning toimus koolikeskkonnas, siis sotsiaalmeedia ja suhtlusportaalide ajastul on nii õpetajatel kui ka õpilastel avanenud võimalus vastastikku ligi pääseda infole, mis jäi varem nende silme eest varjatuks. Enamgi veel, tänu võimalusele omavahel suhtlusportaalides n-ö sõbraks saada, võivad muutuda ka õpetajate-õpilaste suhted klassiruumis.

Uurimustest (Lehrer, 2011; Miller, 2011) nähtub, et kui USAs on käivitunud elav debatt selle üle, kas õpetajatel on eetiline ja juriidiliselt korrektne suhtlusportaalides oma õpilastega suhelda, siis Euroopa kontekstis on see problemaatika siiani pälvinud üsna vähest tähelepanu. Mitmete USA osariikide koolides (nt Louisianas, Missouris, Texases) on vastu võetud eeskirju ja määruseid, mille eesmärk on piirata õpetajate võimalusi suhelda õpilastega sotsiaalmeedia, eriti just Facebooki kaudu (ibid.). Sarnaseid sotsiaalmeedia suhtlust keelavaid eeskirju on Euroopas siiani kehtestatud vähe, nt Saksamaal Schleswig-Holsteini ja Rheinland-Pfalzi liidumaal (German state bans, 2013). Rahvusvahelistes uurimustes on teemat senini käsitletud peamiselt õppejõu-tudengi kontekstis (Malesky \& Peters, 2012) või uuritud õpetajaks óppivate tudengite arvamusi ja tavasid (Hart \& Steinbrecher, 2011; Mikulec, 2012; Olson, Clough, \& Penning, 2009), samas kui põhi- ja keskkooli õpetajate ning õpilaste suhtlust sotsiaalmeedias on vaadeldud vähe (Asterhan, Rosenberg, Schwarz, \& Solomon, 2013; Williams, 2012).

Eestis pole see temaatika laiemat kõlapinda saavutanud. Artikli autoritele pole teada ühtegi kooli, kus oleks õpetajatele välja töötatud sotsiaalmeedias käitumise soovitusi või reegleid. Ka varasematest uurimustest võib nimetada vaid Rooste (2013) tööd, milles kajastati algklassiõpetajate kogemusi ja peamisi suundumusi Facebooki suhtluses oma õpilastega. Välismaa praktiliste kaasuste ning ilmnenud eetiliste ja juriidiliste dilemmade valguses on siiski oluline uurida, mida Eesti õpetajad arvavad õpetaja ja õpilase sõprusest suhtlusportaalis ning milliseid kogemusi neil sellega on.

Uurimustest nähtub, et Eesti õpetajad on küll noorte internetikasutuse vahendajatena üsna aktiivsed (Kalmus, von Feilitzen, \& Siibak, 2012), kuid tunnevad samas ebakindlust enda tehnoloogiliste oskuste suhtes ja tunnistavad vajakajäämisi meediaalases kirjaoskuses (Siibak \& Vinter, 2010). Kuna ajalooliselt on õpetajat peetud keskseks figuuriks ja nõuandjaks (Jedeskog, 2000) ning ühiskondlikult oodatakse talt mentoriks ja eeskujuks olemist ning seetõttu ka keskmisest rangemate eetika- ja moraalistandardite 
järgimist (Miller, 2011), on tähtis välja selgitada, millisena näevad õpetajad oma rolli sotsiaalmeedia nähtamatu auditooriumi ja sotsiaalse konvergentsi tingimustes (Marwick \& boyd, 2010).

Artikli eesmärk on anda ülevaade õpetajate arvamustest ja kogemustest, mis puudutavad õpetajate ja õpilaste interaktsiooni ja sisuloomet suhtlusportaalides. 2013. aasta kevadel-suvel tehtud fookusgrupi intervjuudes nelja kooli keskkooliõpetajatega $(N=21)$ paluti õpetajatel enda kogemuste põhjal kirjeldada oma õpilaste ja endi suhtlusportaalide kasutust ning sealset sisuloomet. Uurimuse seisukohalt pakkus huvi, mis erinevusi olid õpetajad noorte ja endi veebisisu võrreldes täheldanud ning millistel juhtudel ning mil moel on õpetajad pidanud vajalikuks õpilaste postitustele reageerida. Muu hulgas uuriti, kuidas õpetajad ja õpilased saavad suhtlusportaalides sõbraks ning kas tuntakse puudust omavahelist sotsiaalmeedia suhtlust reguleerivatest käitumisjuhistest.

\section{Teoreetiline ülevaade}

\section{Põlvkonnad tehnoloogiliste muutuste ajajärgul}

Tänapäeva noori on sageli nimetatud netipõlvkonnaks, s.t esimeseks põlvkonnaks, kes kasvab üles digitaalsest meediast ümbritsetuna ning kel on esimest korda ajaloos ühiskonna seisukohalt keskse tehnoloogia valdkonnas paremad teadmised ja oskused kui nende vanematel (Tapscott, 1998).

Meedia ja infotehnoloogiliste vahendite kiirest arengust tingitud muutused kultuuri ülekandumise ja sotsiaaliseerumise vormides on osa autorite hinnangul soodustanud nii sotsiaalsete kui ka vanuseliste rühmade vaheliste erinevuste teket (Arnoldi, 2011). Niisamuti leidub käsitlusi (nt Prensky, 2001; Tapscott, 1998), mille kohaselt on digitaalse tehnoloogia kiire areng, kättesaadavus ja põimitus igapäevategemistesse tekitanud lõhe noorema, $\mathrm{nn}$ digitaalsete pärismaalaste ja vanema, $\mathrm{nn}$ digitaalsete immigrantide põlvkonna vahele, kelle nooruspõlve sotsialiseerumis- ja suhtlustavad ei olnud mõjutatud internetist ega tehnoloogilistest vahenditest, vähemalt mitte sellisel määral, kui see on tänapäeva keskkooliõpilastel. Viimastel aastatel pole sellest tehnoloogilisest determinismist kantud arusaamad põlvkonna käsitlustes siiski enam domineerinud.

\section{Suhtlusportaalid ja nende auditoorium}

Ellisoni ja boydi (2013) sõnul on tänu interneti levikule inimestevahelises suhtluses toimunud palju suuri muutusi. Sotsiaalmeedia, eriti aga erine- 
vad suhtlusportaalid, nagu Facebook, LinkedIn ja Google Plus, on saanud paljude jaoks igapäevaelu lahutamatuks osaks.

Suhtlusportaalide toimimise seisukohalt peetakse esmatähtsaks kasutajaid, kes suhtlusportaali erinevate tegevustega elus hoiavad (ibid.). Kontaktide loend ehk sõbralist, kuhu lisatakse kõik, keda peetakse oma sotsiaalse ringkonna osaks, muutub aga suhtlusportaalide kontekstis jagatava info kujutletud ja soovitud auditooriumiks (boyd, 2010). Endaga võrreldes võimupositsioonil olevate indiviidide, nt vanemate, ülemuse või õpetaja ehk nn košmaarsete lugejate (Marwick \& boyd, 2010) lisamist suhtlusportaali sõbralisti võib pidada üsna riskantseks. Kuna sõbralisti liikmestaatusega kaasneb tihtipeale juurdepääs traditsiooniliselt privaatseks peetud infole (nt vanus, töökoht, hobid, poliitilised vaated, suhtestaatus, seksuaalne orientatsioon), tuleks sõbralisti kasutajaid lisades mõelda, mida, kui sageli ja kellele jagatakse (Shih, 2011). Samas ei pruugi sotsiaalmeedia tegelik ja kujutletav auditoorium sugugi kokku langeda, sest jagatavale infole on juurdepääs palju suuremal kollektiivil. Kuna suhtlusportaalide kasutajad ei adu päris täpselt, kes on nende tegelik auditoorium, siis tuginetakse kujutletava auditooriumi loomisel sotsiaalmeedia keskkonnas varem kogetule (Marwick \& boyd, 2010), millest võib järeldada, et sotsiodemograafilised ja kultuurilised erinevused mõjutavad oluliselt indiviidide arusaamu sotsiaalmeediast ja selle auditooriumist.

Peale selle, et inimesed ei pruugi tajuda, kui paljudeni ja kelleni täpselt nende suhtlusportaali n-ö jalajälg ulatub, peetakse sotsiaalmeedia eripäraks erinevate auditooriumide kokkusulamist üheks suureks auditooriumiks ehk nähtust, mida mitmed teoreetikud, sh boyd (2008), nimetavad sotsiaalseks konvergentsiks. Sotsiaalse konvergentsi puhul on kõige olulisem sotsiaalne kontekst, mis määrab indiviidi käitumise vastavalt olukorrale. Kuna suhtlusportaalides on erinevad sotsiaalsed rühmad ühte sulanud, on inimesed justkui ilma jäetud käitumist reguleerivatest sotsiaalsetest normidest, mille abil kontekstuaalsust konstrueeritakse (boyd, 2008; Nissenbaum, 2004).

Nissenbaumi (2004) järgi on siiski peaaegu igas kontekstis olemas normid info ja selle levitamise kohta. Ta eristab kahte tüüpi info edasikandumisega seotud norme - kohasuse (appropriateness) ja levitamise (distribution) norme -, mille järgimine aitab säilitada kontekstuaalset terviklikkust (contextual integrity). Kontekstuaalne terviklikkus hõlmab aega, kohta, tavasid, kultuuritraditsioone jm aspekte, mis reguleerivad ja mõjutavad indiviidi elusündmusi. Kohasuse normid määravad kindlaks, millist infot on või ei ole indiviidi kohta sobilik ja aktsepteeritav konkreetses kontekstis avaldada, info levitamise normid on aga seotud vaba valiku ja diskreetsuse, samuti 
vajaduse ja kohustusega ehk sellega, millal info avaldamine on või ei ole sobilik ja aktsepteeritav.

Kohasuse ja levitamise normid on eriti olulised privaatse info puhul, mille jagamisel võivad olla ulatuslikud negatiivsed tagajärjed. Westin (1968, lk 7) defineerib mõistet privaatsus kui „indiviidide, rühmade või institutsioonide õigust otsustada, millal, kuidas ja millisel hulgal infot nende endi kohta teistele antakse". Seevastu internetiajastu on endaga kaasa toonud uue ja hoogustunud arutelu privaatsuse tähenduse ja olemuse üle, sest küberruum on teinud isikliku info kogumise lihtsamaks kui kunagi varem ja ligipääs erasfäärile on suurenenud nii ruumis kui ka ajas, nii et indiviidi minevikusündmused võivad muutuda kättesaadavaks kõigile, kellel on internetile ligipääs (Chander, 2010).

\section{Õpetajad suhtlusportaalide kasutajatena}

Ka õpetajate kommunikatsioonivormid on tänu suhtlusportaalidele muutumas ning õpetaja-õpilase vahelise suhtlusportaali sõpruse tulemusena on tekkinud mitmeid uusi õiguslikke, eetilisi ja professionaalseid küsitavusi (Russo, Squelch, \& Varnham, 2010).

Õpetajate-õpilaste suhete aspektist on selles interaktsioonis täheldatud nii positiivseid kui ka negatiivseid külgi. Näiteks on osa õpilaste arvates Facebooki konto teinud õpetaja eesmärk luua oma õpilastega positiivseid suhteid ja mõista seeläbi tänapäevast ópilaskultuuri (Mazer, Murphy, \& Simonds, 2007). Et mitte asjatult petta õpilaste ootusi, peaks õpilaste arvates ópetaja eneseväljendus suhtlusportaalis jääma samasuguseks nagu klassiruumiski (ibid.). Mitmetest USAs tehtud uuringutest aga nähtub, et õpetajate ja õpetajaks õppivate tudengite käitumine suhtlusportaalides võib olla kohati üsna vastutustundetu. Näiteks leidsid Olson jt (2009), et enam kui pooled nende valimisse sattunud algklassiõpetajaks õppivatest tudengitest olid oma Facebooki profiilidele postitanud seksuaalse alatooniga või alkoholitarbimist kujutavaid fotosid või kuulusid alkoholitarbimisele viitavatesse gruppidesse. Olsoni jt (2009) arvates võivad seda tüüpi postitused olla muu hulgas tingitud sellest, et Facebooki olemus justkui soodustab selliseid postitusi, sest tagasisides märgitakse harva, et postitust peetakse ebasobivaks. Samas leidsid Kimmons ja Veletsianos (2014), et ka alles õpetajakoolitust läbivad tudengid on seisukohal, et nii tulevaste kui ka juba töötavate õpetajate staatus eeldab neilt eeskujulikku käitumist igas kontekstis. Siinkohal on siiski oluline märkida, et õpilaste suhtumine õpetaja sotsiaalmeedia kasutusse ei sõltu ainult õpetaja enda postitustest, vaid ka tema kontaktide loodavast sisust (Mazer et al., 2007). 
Ennetamaks negatiivseid kogemusi ja võimalikke probleeme, on mitmed USA osariigid või väiksemad haldusüksused õpetaja-õpilase läbikäimist suhtlusportaalides õigusnormidega reguleerinud. Näiteks on New Yorgi haridusosakonna välja töötatud sotsiaalmeedia juhisdokumendis osutatud, et koolitööga seoses tuleks kasutada vaid õppe-eesmärkide täitmiseks loodud sotsiaalmeedia keskkondi ja järgida samu reegleid mis klassiruumiski (NYC Department of Education, 2013). Samuti on selles dokumendis kirjas, et õpetajad ei tohiks isiklikel sotsiaalmeedia lehekülgedel oma praeguste õpilastega suhelda, vältimaks professionaalse suhte muutumist familiaarseks.

Suhtlusportaalide kasutus tekitab vastakaid tundeid ka õpetajate endi seas. Mikuleci (2012) uurimusest nähtub, et 38\% 64-st uuringus osalenud õpetajaks õppivast tudengist leidis, et sotsiaalvõrgustike kaudu on sobilik õpilastega suhelda juhul, kui nad hoiavad oma isikliku ja ametiga seotud Facebooki lehekülje teineteisest lahus, seevastu $15 \%$ valimisse kuulunutest oli seisukohal, et õpetaja ei tohiks mitte mingil juhul kasutada õpilastega suhtlemiseks Facebooki, sest see võib hägustada õpetaja- ja sõbrasuhte piiri.

\section{Uurimisküsimused}

Varasemate empiiriliste uurimuste tulemuste ja selle uurimuse eesmärkide põhjal püstitati kaks peamist uurimisküsimust:

1) kuidas iseloomustavad õpetajad enda ja oma õpilaste sisuloomet suhtlusportaalides?

2) mida arvavad õpetajad õpetaja-õpilase lävimisest ja sõprusest suhtlusportaalides ning milliseid kogemusi neil sellega on?

\section{Metoodika}

\section{Valim}

Valimi moodustamiseks võeti kasutusele kriteeriumid, mis võimaldaks valimisse valitud õpetajatel etteantud teemal kaasa rääkida ja annaks võimalikult palju uuritavate isiklikul kogemusel põhinevaid uurimisandmeid. Valimi kriteeriumid olid järgmised:

1) õpetajatel on või on olnud sotsiaalvõrgustiku kasutajaprofiil;

2) õpetajad õpetavad keskkooli astmes, sest nii on suurem tõenäosus, et õpetajad lisavad selle õppeastme õpilasi sotsiaalvõrgustikes kontaktide hulka;

3) igasse fookusgruppi kuulub vähemalt üks klassijuhataja, sest klassijuhatajatel on oma klassi õpilastega lähedasem suhe kui aineõpetajatel. 
Fookusgrupi intervjuude puhul otsustati intervjueerida koos ühe kooli õpetajaid, et lihtsustada intervjueerimisprotsessi nii õpetajate kui ka uurijate jaoks ning teha see õpetajatele võimalikult mugavaks, sest tegemist võis olla veidi tundliku teemaga. Valimi moodustamisel tuli arvesse võtta asjaolu, et mõned intervjuuküsimused olid ka koolide, mitte ainult õpetajate kohta.

2013. aasta kevadel-suvel tehtud neljas rühmaintervjuus osales 21 õpetajat: 18 naist ja 3 meest. Vanuseliselt jäid fookusgruppidesse kuulunud õpetajad 23-51 eluaasta vahele ning jagunesid järgmiselt: 20 . aastates intervjueeritavaid oli kolm, 30. aastates seitse, 40. aastates samuti seitse ja 50. aastates neli. Ajaliselt esimeses fookusgrupi intervjuus osalenute hulgas oli viis aineõpetajat, kellest neli olid ka klassijuhatajad. Teise fookusgruppi kuulus viis aineõpetajat, kelle hulgas oli kolm klassijuhatajat. Kolmanda fookusgrupi moodustas kuus aineõpetajat, kelle hulgas oli neli klassijuhatajat, ja viimase fookusgrupi viis aineõpetajat, kellest üks oli ka klassijuhataja.

Intervjuusid oli kokku neli, millest kolm viis läbi selle artikli esimene autor. Intervjuud toimusid kooli ruumides ja vältasid üks-kaks tundi. Intervjuud salvestati diktofonile ja transkribeeriti. Transkriptsioonide pikkus kokku on 103 lehekülge, ühe keskmise transkribeeritud intervjuu pikkus on 26 lehekülge. Igale intervjueeritavale anti transkribeerimise käigus kood, et lihtsustada andmete eristamist ja hilisemat analüüsi. Koodid koosnesid intervjueeritava soost, mis on märgitud tähega $\mathrm{N}$ (naine) või $\mathrm{M}$ (mees), ja vastanuid eristavast numbrist (iga fookusgrupiga suurenesid ka numbrid).

\section{Mõõtevahend}

Uuringus rakendati kvalitatiivset käsitlusviisi ning empiiriliste andmete kogumiseks kasutati poolstruktureeritud ülesehitusega fookusgrupi intervjuud.

Meetodit valides sooviti osalejate jaoks luua olukord, kus nad saaksid oma vaateid ja arvamusi esitada kaaslaste mõttearenduse kontekstis, nendega nõustuda või neile vastu vaielda ja seeläbi üheskoos avastada analüüsitava teema eri tahke (Patton, 2002). Fookusgrupi intervjuude miinusteks on peetud intervjueeritavate rohkusest tingitud vastamisvoorude ajalist piiratust, ebaoluliste teemade esilekerkimist, rühmaliikmete omavahelise mõjutamise võimalust (ibid.) ja keerulist analüüsiprotsessi, mis on tingitud nõudest arvestada vestluse kontekstiga (Krueger, 1988). Meetodi kitsaskohtadest hoolimata otsustasid selle artikli autorid fookusgruppide kasuks.

Fookusgrupi intervjuu kava koostades jälgiti, et esitatavad küsimused võimaldaksid saada vastuseid kõigile uurimisküsimustele ja aitaksid koguda võimalikult mitmesuguseid andmeid. Samuti järgiti põhimõtet, et vastajad 
saaksid liikuda üldisematelt teemadelt kitsamatele. Siinses artiklis antakse ülevaade nendest intervjuukava teemadest, mille raames käsitleti järgmisi küsimusi.

1) Milliseid õpilaste postitusi on suhtlusportaalides märgatud? Millist sisu loovad suhtlusportaalides õpetajad ise? Millist infot peetakse ebasobivaks postitada? Kas ja kuidas peaks õpetajad õpilastepoolse ebasobiva sisu postitamisele reageerima? Millist reageerimisviisi peetakse kõige sobivamaks ja miks?

2) Mida peetakse privaatseks infoks? Kuidas on arusaam privaatsusest suhtlusportaalide populaarsusega seoses muutunud?

3) Kuidas suhtutakse õpetaja ja õpilase sõprusesse suhtlusportaalides? Kelle initsiatiivil peaks suhtlusportaali sõprus alguse saama? Kas koolides on olemas juhtnöörid suhtlusportaalides lävimise kohta või kas sellised juhtnöörid peaksid olema?

\section{Analüüsiprotseduur}

Intervjuude analüüsimiseks kasutati tavapärast kvalitatiivset sisuanalüüsi (conventional qualitative content analysis), mille puhul tuletatakse kodeerimiskategooriad otse kogutud tekstiandmetest ja rakendatakse kirjeldava suunitlusega analüüsi (Hsieh \& Shannon, 2005). See meetod on eriti õigustatud juhul, kui varasemaid empiirilisi uurimusi või teoreetilist kirjandust uurimisteema kohta napib (ibid.).

Andmeid analüüsides kõrvutati intervjuusid alateemade ehk küsimuste plokkide kaupa, et saada parem ülevaade ühte suuremat teemat puudutavatest vastustest, kogemustest ja hinnangutest. Pärast ühe intervjuu alateema läbitöötamist pöörduti järgmise intervjuu sama alateema küsimuste juurde, et selgitada juba varajases kodeerimisprotsessis välja, milliseid sarnasusi ja erinevusi on kõigi intervjuude põhjal võimalik leida. Kodeerimisühikuks võeti üks rida ja alustati tekstilähedase kodeerimisega, sõnastades kategooriaid pigem teksti iseloomustavate lausetena. Seejärel püüti kategooriaid sõnastada abstraktsemalt (Mayring, 2000). Kõigepealt koondati kõigi intervjuude puhul sarnased kategooriad alateemade kaupa ja seejärel otsiti sarnasusi kõigist teistest alateemadest. Alakategooriad, mis tekstide läbitöötamisel tekkisid, olid näiteks „erinevused privaatsuse tajumisel”, „vastandumine õpilaste sisuloomepraktikale”, „osaline infosulg suhtlusportaalis”, „õpetaja kui eeskuju”, „õpetaja rolli muutumatus”, „, häiriv sisuloome”, „kahju tekitav sisuloome”, „diskreetne sekkumine”, „mittediskreetne sekkumine”, „sõbraks võtmise kriteeriumid”, „reeglite mittevajamine”. 


\section{Tulemused ja arutelu}

\section{Suhtlusportaalide kasutamisega ilmnevad põlvkondlikud erinevused}

Uuringus osalenud õpetajate isiklikest kogemustest ja antud hinnangutest nähtub, et kooliõpilaste ja täiskasvanute internetikäitumine suhtlusportaalides on väga erinev. Üheks põhiliseks erinevuseks pidasid intervjueeritud õpetajad õpilaste teisenenud privaatsustaju. Noored loovad õpetajate hinnangul tihtipeale suhtlusportaalides sisu, mis võiks kuuluda indiviidi privaatsfääri, kuid mis Facebooki kaudu jõuab tunduvalt laiema auditooriumini, kui see on kohane. Õpetajate arvates ei seosta õpilased suhtlusportaale sageli avaliku ruumiga ega taju seetõttu oma postitusi tehes potentsiaalse auditooriumi suurust.

Minu meelest paljud ei saa üldse aru ka sellest, et nad on internetis, ja nad arvavad, et nad on seal peaaegu et salaja, no mitte salaja, aga niimoodi, et ei lähe, aga tegelikult lähevad andmed sealt meile teadmatult kohe edasi kuskile. Nii kui sa kuskile midagi salvestad või millegagi ühined, siis kohe on andmed igal pool laiali minemas, mida sa ise üldse ei tea. /---/ Noored ei tea neid ohte üldse. Noh, nad arvavad, et kõik on privaatne, aga tegelikult ei ole. (N15)

Eesti noorte üsna muretut suhtumist privaatsusesse ning probleeme suhtlusportaalide auditooriumi suuruse hindamisel on täheldatud ka mitme varasema uuringu põhjal (Murumaa \& Siibak, 2012; Oolo \& Siibak, 2013). Õpetajate kogemustest nähtus, et nende kui „košmaarsete lugejateni” (Marwick \& boyd, 2010) jõuab suhtlusportaalide vahendusel tihtipeale ka sellist infot, mida väljaspool virtuaalkeskkonda neile tegelikult ei avaldataks.

Ühest küljest leidsid uuringus osalenud õpetajad, et õpilaste seesugune suhtlemine on tüüpiline noorte inimeste käitumine, ning nad olid seisukohal, et suhtlusportaalidest on saanud noorte jaoks niivõrd igapäevased ja võltsi turvatunnet tekitavad keskkonnad, mistõttu ei tajuta sageli oma käitumise võimalikke negatiivseid tagajärgi. Lisaks leiti, et kuna tänapäeva noored on internetis üles kasvanud, on neil keeruline aduda sellist privaatsuse käsitlust, mis on omane vanemale, nn digitaalsete immigrantide põlvkonnale (Prensky, 2001). Kuna praegused kooliõpilased on suhtlusportaalide ja uute ühiskondlike normidega nii harjunud, tuleb uuringus osalenud õpetajate arvamuste põhjal välja omamoodi digitaalne lõhe, mis ei puuduta niivõrd digitaalse tehnoloogia kasutamise oskust, vaid sellega kaasas käivaid uusi käitumisnorme. Kuna õpilased lävivad suhtlusportaalides enamjaolt oma eakaaslastega, kelle käitumisest ka eeskuju võetakse, siis võib eeldada, et samade sotsiaalsete normide taastootmine jätkub (Marwick \& boyd, 2010). 
Samas tõdesid fookusgruppidesse kuulunud õpetajad, et nende õpilaste hulgas leidub siiski ka neid, kes tajuvad internetti avaliku ruumina ning mõistavad erinevust privaatse ja avaliku info vahel. Näiteks olid ühe fookusgrupi liikmed arvamusel, et õpilaste teadlikkus privaatsusega seotud teemadest on viimasel ajal kasvanud, sest see on meedias ja ühtlasi ühiskonnas leidnud laiemat kõlapinda. Samuti arvati, et teadlikkuse kasv on seotud õpilaste endi negatiivsete kogemustega ning keskkooliõpilaste puhul ka vanuse suurenemisega.

Jah, aga gümnaasiumieas ma tean, konkreetselt minu klassis, neil on päris mitu gruppi, kus nad suhtlevad. Nad on päris mitmeid erinevaid gruppe teinud. See näitab, et mingil määral nad ikka tahaksid ka, et kogu info kõigini ei jõua. (N9)

Ei, loogiline, aga seal on juba täiskasvanud. (N8)

Selline klassi või erihuvidega seotud gruppide loomine on õpetajate hinnangul muutunud õpilaste hulgas üha sagedasemaks, nii et osa õpilaste tegemistest jääb suhtlusportaalides igal juhul õpetajate eest varjatuks. Näiteks olid fookusgrupi intervjuudes osalenud õpetajad arvamusel, et ka nende endi kohta postitavad noored Facebookis negatiivse alatooniga sõnumeid, kuigi keegi uuringus osalenutest ei osanud selle kohta konkreetseid näiteid tuua. Kinniseid gruppe peeti aga just sellisteks keskkondadeks, kus õpetajad võivad õpilaste hambu sattuda.

Ma arvan, et äkki avalikult, avalikus selles nad ei tee. Kui siis sealsamas klassi kommuunis käib see. (N4)

Ma ei ole reaalselt näinud. (N5)

Me ei näe seda, ma räägin seda, et see käib varjatult, aga käib raudselt. (N4)

Õpetajate sõnul erineb nende endi suhtlusportaalide kasutus selgelt õpilaste omast. Kui noored avaldavad intervjueeritute hinnangul suhtlusportaalides liialt privaatset infot, siis enda sisuloomest rääkides rõhutati, et nende loodav sisu ei kuulu privaatsfääri ja selle hulk on minimaalne, lisaks mainiti selle üleüldist ettevaatlikku kasutust. Olgugi et intervjueeritud õpetajate hulgas leidus ka neid, kes olid oma Facebooki kontole riputanud üles pilte nii endast kui ka oma pereliikmetest või jagasid fotojäädvustusi oma harrastuste, nt käsitöö kohta, siis enamik osalenutest vältis enda sõnul igati privaatsfääri kuuluva sisu - enda või pereliikmete piltide ja muu pereliikmeid puudutava info - jagamist, sest seda ei peetud õpetajale kohaseks. 
No põhimõte on ikkagi selline, et isiklik elu ja pereelu, et noh seda enam, et meie kui õpetaja ei saagi selles suhtes endale sellist asja lubada. Et see on nü̈̈d number üks, ütleks mina. (N3)

Nagu ülaltoodust nähtub, rõhutasid paljud fookusgruppide liikmed, et nende suhtlusportaalide kasutus on mõjutatud nende ametipositsioonist. Nimelt leiti, et just õpetaja staatus on see, mis ärgitab uuringus osalejaid sotsiaalvõrgustike kasutamises ettevaatlikkusele, sest intervjueeritavad tunnetasid kohustust olla oma käitumisega noortele eeskujuks ka suhtlusportaalides. Ettevaatlikkus ei väljendunud siin kontekstis mitte ainult vähese ja mitteprivaatse info avalikustamises, vaid ka postituste ja kommentaaride laikimises, sest seegi info on Facebooki kontaktidele nähtav. Niisamuti kinnitasid Mazeri jt (2007) uuringus osalenud, et nad kaaluvad hoolikalt, milliseid postitusi ja kommentaare nad laigivad.

Näiteks ma väga vaatan isegi seda, mis pilte ma panen laik, meeldib, et ma isegi vaatan, et ma ei paneks mingisugustele, no isegi kui mul emotsioon on hetkel, et oh, jumala äge, et vana klassivend on teinud siin mingisugust pulli värki, ma ei pane sinna laik, sest et ma tean, et võib-olla kuna see on avalik, siis minu õpilasteni läheb see ka. (N16)

Ülaltoodud näide illustreerib tõika, et nii nagu Kimmonsi ja Veletsianose (2014) uuringus osalenud arvasid ka praeguse uuringu valimisse sattunud õpetajad, et õpetajad peaksid korrektselt käituma igas olukorras.

\section{Õpetajate reageeringud õpilaste ebasobivale sisuloomele}

Fookusgrupi intervjuus osalenud leidsid, et nende roll noorte kasvatajate ja harijatena jääb samaks nii klassiruumis kui ka virtuaalses keskkonnas. Enda kui mentori rolli rakendati kõige enam õpilaste loodud postitusi jälgides. Intervjueeritud õpetajate hinnangul postitavad õpilased Facebookis palju sellist sisu, mida saab pidada vähem või rohkem ebasobivaks. Olukorras, kus Facebooki olemus lausa soodustab ebasobiva sisu postitamist (Olson et al., 2009), pole selline õpetajate arvamus üllatav. Postituse sisu määrab aga ära selle, kas õpetaja peab vajalikuks postitusele kuidagi reageerida või mitte.

Intervjuudest nähtus, et üldjuhul ei peeta vajalikuks sekkuda, märgates sellist sisu, mis läheb vastuollu õpetaja isiklike väärtushinnangute või suhtlusportaali kasutustavadega. Ebasobivaks, ent sekkumist mittevajavaks liigitusid õpetajate hinnangul liialt romantilise alatooniga ja selgelt ühele inimesele suunatud kommentaarid või kaastundeavaldused. Tauniti ka liiga sagedast postitamist. 
Õpetajate arvates tuleks ühel või teisel moel sekkuda nende postituste puhul, mida võib kokku võtta väljendiga „enesele või teistele kahju tegema”. Selliste postituste hulka kuuluvad näiteks liiga paljastavad fotod ning pidude jäädvustused ehk nn läbupildid, aga ka solvamine, laimamine ja illegaalsete tegevuste propageerimine. Üldiselt olid intervjueeritud õpetajad arvamusel, et suhtlusportaalides peaks reageerima samasugustele tegevustele nagu koolis või klassiruumiski.

Ma arvan, need teemad on põhimõtteliselt samad, millele õpetaja peab ikka reageerima, kui nad ei ole ka mitte seal Facebookis, vaid oleksid ka reaalelus, tunnis, igasugused äärmuslikud seisukohad, solvamine, laimamine ja siis tood mingeid isiku-, eraandmeid välja inimese kohta või siis propageeri alkoholitarvitamist. (M6)

Ülaltoodud näitest nähtub, et sama moodi nagu Vadrevu (2011) uuringus osalenud õpetajad tunnetasid ka selle uuringu valimisse sattunud selgelt enda kui mentori rolli. Näiteks leidsid õpetajad üksmeelselt, et ebasobivad postitused nõuavad õpetaja sekkumist. Samuti peeti vajalikuks aeg-ajalt õpilastele meelde tuletada, et Facebookis üles riputatud sisu, sealhulgas nn läbupildid, võivad edaspidises elus probleeme tekitada. Ebasobivatele postitustele reageerides lähtuti aga enamasti sellest, kui kiiret tegutsemist õpetaja hinnangul konkreetne juhtum vajas.

Kõige efektiivsemaks sekkumisviisiks peeti õpilasega silmast silma vestlust. Nii mõnedki uuringus osalenud õpetajad olid selliseid vestlusi pidanud ebasobivate fotode teemadel. Näiteks oli üks õpetaja märganud Facebookis fotot, kuhu oli jäädvustatud „valge pulber peeglil”, ehk foto viitas narkootikumide kasutamisele. Kuigi see fotojäädvustus oli tegelikult lavastatud, pidas õpetaja siiski vajalikuks foto postitajaga isiklikult rääkida, sest tema meelest illustreeris see juhtum ilmekalt, kuivõrd oluline on infojagamisel kontekst.

Vist hiljuti oli ühe klassiga, üksteist klassi ka, kus oli pilt siis, et nad lavastasid mingi pildi, et valge pulber peegli peal. /---/ Et tegelikult kui selline pilt pannakse üles, siis ei tee pärast keegi kindlaks, mis seal siis on. Et nad ise saavad küll aru, et see on lavastus, aga ... (M6)

Aga teised ei saa sellest aru. (N10)

Õpetajate arvates ei adu noored tihti, et ühele sihtrühmale mõeldud postitus võib teise sihtrühma jaoks omada hoopis teist tähendust, ehk postitusi tehes kiputakse eirama kontekstuaalse terviklikkuse põhimõtet (Nissenbaum, 2004). 
Samuti leidsid õpetajad, et konkreetsete Facebooki näidete varal peaks klassiruumis laiemalt teema üles võtma, et sarnaseid juhtumeid edaspidi vältida.

Noh, kui sa tahad ikka mõjutada millegagi, siis kui sa vaatad inimesele otsa, siis saad midagi ära rääkida asjalikku. Facebookis, mina ei tea, kuidas nad võtavad seda, mina ei tea. /---/ Kui räägin tõesti, siis võib-olla mõjub paremini. (N15)

Selleks, et mitte noomida õpilast tema sõprade ja klassikaaslaste juuresolekul, olid mõned intervjueeritud õpetajad otsustanud saata ebasobiva postituse tegijale privaatsõnumi. Samas leidus ka neid, kes ei pidanud probleemsete postituste märkamise korral diskreetset sekkumist vajalikuks. Vahetut sekkumist pooldanud õpetajad leidsid, et kui õpilane postitab omal vastutusel avalikku keskkonda midagi ebatsensuurset, siis võib ka õpetaja postitusele avaliku kommentaariga vastata. Sellist eelkõige ropendamist või laimamist sisaldavate postituste puhul rakendatavat reageeringut peeti omamoodi ópetamisviisiks, mis pidi aitama tagada, et seda tüüpi vead ei korduks. Üks fookusgrupi intervjuus osalenud õpetaja leidis näiteks, et endast paljastavaid fotosid üles riputanud õpilastele võiks õppetunni anda kavaluse abil ja postitada pildi alla rinnahoidjate müügikuulutuse. Selline kavalus võib jõuda ka õpilase klassi- ja koolikaaslasteni, millest ilmneb, et ka õpetajatel endil puudub kohati arusaam sotsiaalmeedia auditooriumi suurusest.

\section{Õpetaja-õpilase sõprus suhtlusportaalis}

Nii nagu Williamsi (2012) uuringus osalenud, möönsid ka intervjueeritud õpetajad, et Facebookis võivad õpetaja ja õpilase sõbrasuhte piirid hägustuda ning ära kaduda distants, mida õpetaja-õpilase suhe eeldab. Sellegipoolest olid paljud siinses uuringus osalenud õpetajad oma õpilastega suhtlusportaalides sõbrasuhetes või oli pea kõigil neil olnud selliseid sõbrasuhteid. Erinevalt näiteks paljude USA osariikide praktikast, kus õpetajatel ei soovitata enda isikliku suhtlusportaali profiili kaudu õpilastega suhelda (NYC Department of Education, 2013), oli enamik intervjueeritud õpetajatest oma õpilastega suhelnud Facebookis, aga ka Orkuti või Rate’i keskkonnas.

Intervjuudest nähtub, et õpetaja-õpilase suhtlusel on tavaliselt kaks võimalikku vormi: 1) õpilased on lisatud õpetaja kontaktide listi ehk sõbralisti, 2) õpetaja kuulub klassi loodud ühisgruppi. Intervjueeritud õpetajate hulgas oli üsna levinud mõlema variandi paralleelkasutus. 
Intervjuude põhjal selgus, et õpetajad järgivad õpilaste vastuvõtmisel oma suhtlusportaali sõbralisti puhul teatud põhimõtteid. Näiteks ilmnes, et mida sagedasem ja lähedasem oli õpetaja kontakt õpilasega, seda suurem oli ka tema sõbralisti lisamise tõenäosus. Ehk erinevalt USAs levinud sotsiaalmeedia juhenditest, kus õpetajatel soovitatakse liigse familiaarsuse kartuses isiklikke suhtlusportaali profille õpilastega suhtlemiseks mitte kasutada (NYC Department of Education, 2013), oli intervjueeritud õpetajate jaoks isiklikum suhe õpilasega eeldus, millest lähtuti õpilase lisamisel suhtlusportaali sõbralisti. Intervjuudele tuginedes võib väita, et klassiõpetajatel on suurem tõenäosus luua õpilastega Facebooki vahendusel sõbrasuhteid kui aineõpetajatel. Kuna klassiõpetajad peavad oluliseks, et õpilased tunneksid end nende klassi kuuludes hästi (Poom-Valickis \& Löfström, 2014), siis on mõistetav ka nende suurem motivatsioon oma õpilastega suhtlusportaalides kontakti ning positiivseid suhteid hoida (Mazer et al., 2007).

Intervjueeritud õpetajate jaoks oli tähtis, et nad tunneksid õpilast enne Facebooki sõprade hulka vastuvõtmist isiklikult, kas siis aine õpetamise või mõne koos organiseeritud kooliürituse või huvirühmas osalemise kaudu. Seda, kui õpilane, kellega õpetajal ei ole olnud mingisugust kokkupuudet, esitab Facebookis sõbrakutse, peeti isegi imelikuks ja selliseid sõbrakutseid valimisse sattunud õpetajad tavaliselt ignoreerisid. Õigupoolest oli õpilase sõbrakutse eiramine intervjueeritute hulgas isegi üsna tavaliseks praktikaks ega tekitanud kordagi pikemat arutelu selle üle, kuidas võiks selline käitumine kutse saatnud õpilasele mõjuda. Vaid üks õpetajatest mainis, et sõbrakutse eiramine võib ehk õpilast solvata, mille peale tuli teiselt õpetajalt kiire vastus, et „mis ta ikka solvub”. Sama õpetaja oli ka seisukohal, et vastama ei pea ka sõnumitele, mille on õpilased õpetajale Facebooki jätnud.

Ja samas ega ei pea ju vastama ka, kui näiteks mul mõned algklassilapsed, kes mul seal sõbraks sattusid, kirjutavad, et tere, kuidas läheb või kuidas elad, et ma lihtsalt ei vasta, ma tõesti tee väljagi, las nad kirjutavad, ei pea ju vastama. (N9)

Kuigi õpetajatel võib tõesti suhtlusportaali koguneda hulgaliselt õpilaste sõbrakutseid ja privaatsõnumeid, võib selline vältimistehnika õpilaste jaoks olla sügavama tähendusega, kui täiskasvanud oskavad ette kujutada, sest „digitaalsete põliselanike” (Prensky, 2001) jaoks ei eksisteeri virtuaalse ja n-ö päris maailma vahel piire. Mazeri jt (2007) uuringu tulemustest lähtudes võib väita, et just seetõttu peaks õpetaja eneseväljendus ja suhtlemisstiil olema sotsiaalmeedias samasugune kui klassiruumis. Teisisõnu võib koolis igati suhtlusalti õpetaja vastupidine käitumine suhtlusportaalis saata õpilastele vastakaid signaale, mis omakorda võib negatiivselt mõjutada 
õpilase-õpetaja suhtlust tervikuna. Ka Kimmons ja Veletsianos (2014) on toonitanud, et õpetajad peaksid suhtlusportaale kasutades arvestama, et nende sealset käitumist tõlgendavad erinevad sotsiaalsed rühmad.

Peale enda klassi õpilaste olid intervjuus osalenud õpetajad valmis kontaktide listi lisama ka neid õpilasi, kes oma Facebooki kasutuselt sarnanesid õpetajatega ehk on pigem jälgijad kui tegutsejad ning ei postita ebatsensuurset sisu. Samuti oli õpilase sõbraks võtmise puhul oluline vanus. Algklassilapsi ja põhikooli algusastme õpilasi fookusgrupi intervjuus osalenud õpetajad üldjuhul oma kontaktide hulka ei lisanud ning tegelikkuses ei tohiks ka nende vanus lubada neil omada Facebooki kontot.

Sama moodi nagu Mikuleci (2012) uuringu puhul, oli ka praeguses uuringus osalenute hulgas neid, kes ei aktsepteerinud üldse õpilaste sõbrakutseid. Enda otsust põhjendati sellega, et suhtlusportaale nähakse eelkõige eakaaslastega suhtlemise keskkonnana, mis võimaldab võtta aega enese jaoks ning eristada seeläbi tööd ja isiklikku elu.

Ma olen lastele ka ütelnud, et minu privaataeg on minu aeg. Ma ei taha kell 10 õhtul mingi lapsega suhelda seal. Esiteks, ma pole klassijuhataja ka, seega mul ei ole ehk selliseid probleeme, mis teistel. See ka, et esiteks ma võin ära piirata, aga ma tahan nii, et mul oleks tööaeg ja vaba aeg. Ma ei pea olema lapsele 24 tundi kättesaadav. (N21)

Üheselt leiti, et sõbrakutse peaks esitama õpilane, ning vastupidist situatsiooni peeti kohaseks vaid erandjuhtudel, näiteks kui õpilasega on varem selles kokku lepitud. Kui praeguste õpilaste kohta kehtivad mitmed vastuvõtukriteeriumid, siis endisi õpilasi lisatakse kontaktide hulka lihtsamini, kuigi ka nende puhul ei esita õpetaja tavaliselt ise sõbrakutset.

\section{Õpetajate suhtumine sotsiaalmeedia käitumisjuhistesse}

Erinevalt näiteks USAst, kus õpetaja-õpilase sotsiaalmeediasuhtlus on üldjuhul üsna rangelt reglementeeritud (Lehrer, 2011), olid praeguses uuringus osalenud õpetajad seisukohal, et õpetaja-õpilase läbikäimine suhtlusportaalides ei nõua mingisuguseid erireegleid ega -juhiseid ning netisuhtlusel peaks johtuma tavalistest ühiskondlikest eetika- ja moraalinormidest, sest need kehtivad igal pool ühtviisi. Kuna ka endi kogemust õpetajana pidasid valimisse sattunud õpetajad piisavaks, siis leiti üksmeelselt, et õpetajad on intelligentsed inimesed ning ei vaja seetõttu lisajuhiseid ega käitumiskoolitusi. 
Neid normatiive on elus niigi palju ja siin on ikka intelligentsed õpetajad töötavad koolis, ma arvan, et seda, kuidas nemad suhtlevad Facebookis ja kellega, seda nüüd küll ei ole vaja reguleerima hakata ametlikul tasandil koolis. (N14)

Samas tunnistasid õpetajad, et neil puuduvad ka kogemused, mis võiksid tekitada soovi ja vajadust reeglite väljatöötamise järele, st õpetajatel ei ole olnud ühtegi sellist kokkupuudet mõne teise õpetajaga, kelle käitumine suhtlusportaalides oleks läinud üldiste eetika- ja moraalinormidega vastuollu, nagu on täheldatud mitmetes USAs tehtud uuringutes (Hart \& Steinbrecher, 2011; Olson et al., 2009). Üldiselt leiti, et õpetajad käituvad suhtlusportaalides vastutustundlikult ja õpetaja staatusele kohaselt.

\section{Järeldused}

Uurimistulemustest nähtub, et õpetajad tunnetavad õpilastega suhtlusportaalides suhtlemisel selget professionaalset dilemmat. Niisamuti nagu on täheldanud Asterhan jt (2013), tekkisid ka meie uuringus osalenud õpetajate jaoks dilemmad peamiselt privaatsuse ning autoriteetsuse $v$ s. sõbrasuhte küsimustes. Valimisse sattunud õpetajad hoidusid suhtlusportaalis enda professiooni seisukohalt ebasobiva sisu postitamisest, kuid leidsid, et õpilased on sotsiaalmeedias liiga varmad jagama infot, mida vanemad põlvkonnad liigitaksid privaatsfääri kuuluvaks. Õpetajad olid valmis kohe reageerima sellistele õpilaste postitustele, mis võisid nende hinnangul mingil moel kahjustada kas õpilast ennast (nt liiga paljastavate fotode lisamine) või kedagi teist (nt küberkiusamine). Eeltoodust ilmneb, et sama moodi nagu Williamsi (2012) uuringus osalenud tunnetavad ka siinse uurimistöö raames intervjueeritud õpetajad suhtlusportaali kasutades vajadust olla enda veebikäitumisega õpilastele eeskujuks ning omamoodi kohustust õpetada neile õiget netiketti. Sotsiaalmeedia rolli informaalse õpikeskkonnana, mis lausa nõuab täiskasvanupoolset sotsiaalset vahendamist ja seiret, on toonud esile ka Asterhani jt (2013) uuringus osalenud õpetajad.

Fookusgrupi intervjuus osalenud õpetajate kogemused ja arvamused võimaldavad oletada, et osalejad ei ole mitte "digitaalsed immigrandid”, vaid üsna kogenud ja oskuslikud internetikasutajad, kes on valmis õpilaste suhtlusportaalide kasutust suunama. Õpetajad tajuvad üsna hästi, kuivõrd oluline on sotsiaalmeedia nähtamatu auditooriumi tõttu lähtuda postitusi tehes kontekstuaalse terviklikkuse põhimõttest (Nissenbaum, 2010). Samas peegeldab fookusgrupi intervjuus osalenute suhtumine kahjuks seda, et õpetajad ei näe Facebookis ja sotsiaalmeedias võimalust arendada õpilastega 
kahepoolset suhtlust. Erinevalt Williamsi (2012) uuringus osalenud õpetajatest, kes toonitasid, et sotsiaalmeedias peaks õpetaja-õpilase suhtlus olema rajatud võrdsetele alustele, ei väljendunud samasugune arvamus praeguses uuringus osalenute seisukohtades. Pigem nähtus, et valimisse sattunud õpetajad ei võta õpilasi suhtlusportaalides võrdsete suhtluspartneritena. Näiteks püüdsid mõned uuringus osalenud õpetajad õpilaste saadetud teateid eirata ja ei pidanud vajalikuks neile vastata. Samuti ei näinud intervjueeritud õpetajad eetilist dilemmat selles, et suhtlusportaalide kaudu jõuab nendeni hulgaliselt õpilaste privaatsfääri kuuluvat infot, samas kui enda isikliku elu detaile ei oldud enamjaolt nõus õpilaste pilgu all jagama. Õigupoolest olid fookusgruppidesse kuulunud õpetajad veendunud, et nad ise ja ka nende kolleegide käitumine sotsiaalmeedias on eeskujulik ning vastab eetika- ja moraalinormidele. Erinevalt teistes riikides (nt USAs) laialt levinud praktikast ei tunnetatud vajadust konkreetsete käitumisreeglite või kooli juhiste järele.

Uuringus osalenud õpetajad ei pidanud õpetaja-õpilase suhtlust suhtlusportaalides kuigi tähtsaks ning nad ei leidnud, et see võiks õpetaja-õpilase suhteid märkimisväärselt mõjutada. Kuna tegevus suhtlusportaalides võib digitaalset põlvkonda esindavate õpilaste jaoks olla märksa kaalukam, kui õpetajad oskavad arvata, ning õpetaja käitumine peaks õpilaste arvates jääma samasuguseks nii suhtlusportaalis kui ka klassiruumis (Mazer et al., 2007), võivad õpetaja-õpilase suhteid mõjutada ka need nn sõbraks saamise kriteeriumid, mille on õpetajad õpilaste teadmata kasutusele võtnud. Selleks, et mõlemad pooled oleksid üksteise tavadest teadlikud ning mõistaksid neid paremini, võiksid õpetajad õpilastega suhtlusportaali sõpruse ja netiketi teemad julgemalt ja tihemini ka klassiruumis arutluse alla võtta. Kuna paljud noored ei taju veel piisavalt hästi suhtlusportaalides valitsevat sotsiaalset konvergentsi (Murumaa \& Siibak, 2012; Oolo \& Siibak, 2013), siis võiks ühiste mängureeglite kehtestamine olla mõlema poole jaoks sõbraliku ja usaldusliku läbisaamise aluseks.

Kuna tehtud uuring on väikesel valimil põhinev prooviuuring, kus osalesid end pigem passiivseks suhtlusportaalide kasutajaks pidavad õpetajad, ei ole tulemusi võimalik üldistada ega laiendada kogu Eesti õpetajaskonnale. Samuti tuleb tunnistada, et kuna õpilaste ja õpetajate interaktsiooni suhtlusportaalides on ka rahvusvahelisel tasandil vähe uuritud, oli praeguse uuringu tulemuste kõrvutamine varasemate empiiriliste leidudega keeruline.

Kuna selle valdkonna uurimisega on Eestis siiani vähe tegeletud, kuid teema on infoühiskonna kontekstis väga aktuaalne, siis pakuvad eelmainitud puudustest hoolimata uurimistulemused siiski uusi teadmisi õpetaja-õpilase interaktsioonist ja sisuloomest suhtlusportaalides. Samas on uute sama- 
sisuliste uuringute tegemine kindlasti vajalik. Näiteks oleks õpetajate arvamustele vastukaaluks vaja uurida ka seda, mida arvavad õpilased õpetajatega läbikäimisest suhtlusportaalides. Kindlasti oleks huvitav teada, miks õpilased tahavad õpetajatega suhtlusportaalides kontakti luua ja kuidas mõjutab nende arvates kontakti loomise soovi eiramine õpetaja-õpilase suhet. Tuginedes teistes riikides (nt USAs ja Saksamaal) aina enam levivale praktikale reguleerida õpetajate ja nende hoolealuste suhtlust sotsiaalmeedias, oleks oluline uurida ka meie koolide ning Haridus- ja Teadusministeeriumi seisukohti ühtsete juhtnööride väljatöötamise vajalikkuse kohta.

\section{Tänusõnad}

Artikkel on valminud Eesti Teadusagentuuri rahastatud personaalse uurimisprojekti PUT044 toel.

\section{Kasutatud kirjandus}

Arnoldi, P. (2011). Generational belonging between media audiences and ICT users. In F. Colombo \& L. Fortunati (Eds.), Broadband society and generational changes (Vol. 5, pp. 51-67). Berlin: Peter Lang.

Asterhan, C., Rosenberg, H., Schwarz, B., \& Solomon, L. (2013). Secondary school teacher-student communication in Facebook: Potentials and pitfalls. In Y. Eshet-Alkalai et al. (Eds.), Proceedings of the Chais conference on instructional technologies research 2013: Learning in the technological era. Raanana: The Open University of Israel. Retrieved from

http://www.openu.ac.il/innovation/chais2013/download/e1_3.pdf.

boyd, d. (2008). Facebook's privacy trainwreck: Exposure, invasion, and social convergence. The International Journal of Research into New Media Technologies, 14(1), 13-20. http://dx.doi.org/10.1177/1354856507084416

boyd, d. (2010). Social network sites as networked publics: Affordances, dynamics, and implications. In Z. Papacharissi (Ed.), Networked self: Identity, community, and culture on social network sites (pp. 39-58). New York: Routledge.

Chander, A. (2010). Youthful indiscretion in an internet age. In S. Levmore \& M. C. Nussbaum (Eds.), The offencive internet: Speech, privacy, and reputation (pp. 124-139). Cambridge: Harvard University Press.

Ellison, N. B., \& boyd, d. (2013). Sociality through social network sites. In W. H. Dutton (Ed.), The Oxford handbook of internet studies (pp. 151-172). Oxford: Oxford University Press. http://dx.doi.org/10.1093/oxfordhb/9780199589074.013.0008

German state bans student-teacher contact on Facebook (2013). Capital News. Retrieved from http://www.capitalfm.co.ke/news/2013/10/german-state-bansstudent-teacher-contact-on-facebook/. 
Hart, J. E., \& Steinbrecher, T. (2011). OMG! Exploring and learning from teachers' personal and professional uses of Facebook. Action in Teacher Education, 33(4), 320-328. http://dx.doi.org/10.1080/01626620.2011.620515

Hsieh, H.-F., \& Shannon, S. E. (2005). Three approaches to qualitative content analysis. Qualitative Health Research, 15(9), 1277-1288. http://dx.doi.org/10.1177/1049732305276687

Jedeskog, G. (2000). Teachers and computers: Teachers' computer usage and the relationship between computers and the role of the teacher, as described in international research (Doctoral dissertation). Uppsala University, Uppsala. Retrieved from http://www.diva-portal.org/smash/get/diva2:160752/FULLTEXT01.pdf.

Kalmus, V., von Feilitzen, C., \& Siibak, A. (2012). Effectiveness of teachers' and peers' mediation in supporting opportunities and reducing risks online. In S. Livingstone, L. Haddon \& A. Görzig (Eds.), Children, risk and safety on the Internet. Research and policy challenges in comparative perspective (pp. 245-256). Bristol: Policy Press. http://dx.doi.org/10.1332/policypress/9781847428837.003.0019

Kimmons, R., \& Veletsianos, G. (2014). The fragmented educator 2.0: Social networking sites, acceptable identity fragments, and the identity constellation. Computers \& Education, 72, 292-301. http://dx.doi.org/10.1016/j.compedu.2013.12.001

Krueger, R. A. (1988). Focus groups: A practical guide for applied research. Newbury Park: Sage.

Lehrer, A. (2011). Keep the poking to yourself, Mrs. Robinson: The Missouri Facebook statute and its implications for teacher free speech under the first amendment. Seton Hall Law eRepository. Retrieved from http://scholarship.shu. edu/cgi/viewcontent.cgi?article=1001\&context=student_scholarship.

Malesky Jr., L. A., \& Peters, C. (2012). Defining appropriate professional behavior for faculty and university students on social networking websites. Higher Education, 63(1), 135-151. http://dx.doi.org/10.1007/s10734-011-9451-x

Marwick, A. E., \& boyd, d. (2010). I tweet honestly, I tweet passionately: Twitter users, context collapse, and the imagined audience. New Media \& Society, 13(1), 114-133. http://dx.doi.org/10.1177/1461444810365313

Mazer, J. P., Murphy, R. E., \& Simonds, C. J. (2007). I'll see you on „Facebook”: The effects of computer-mediated teacher self-disclosure on student motivation, affective learning, and classroom climate. Communication Education, 56(1), 1-17. http://dx.doi.org/10.1080/03634520601009710

Mayring, P. (2000). Qualitative content analysis. Forum: Qualitative Social Research, 1(2). Retrieved from http://nbn-resolving.de/urn:nbn:de:0114-fqs0002204.

Mikulec, E. A. (2012). Professional faces: Pre-service secondary teachers' awareness of issues of self-disclosure on social-networking sites. Current Issues in Education, 15(3), 1-16.

Miller, R. A. (2011). Teacher Facebook speech: Protected or not? Brigham Young University Education and Law Journal, 2, 637-665. Retrieved from http://web.a.ebscohost.com/ehost/pdfviewer/pdfviewer?sid=ea72f01e-9bee-48479d16-7e736531acdc\%40sessionmgr4003\&vid=8\&hid=4214. 
Murumaa, M., \& Siibak, A. (2012). The imagined audience on Facebook: Analysis of Estonian teen sketches about typical Facebook users. First Monday, 17(2). Retrieved from http://firstmonday.org/htbin/cgiwrap/bin/ojs/index.php/fm/ article/viewArticle/3712/3147.

http://dx.doi.org/10.5210/fm.v17i2.3712

Nissenbaum, H. (2004). Privacy as contextual integrity. Washington Law Review, 79(1), 119-157. Retrieved from http://www.kentlaw.edu/faculty/rwarner/classes/ internetlaw/2011/materials/nissenbaum_norms.pdf.

Nissenbaum, H. (2010). Privacy in context: Technology, policy, and the integrity of social life. California: Stanford University Press.

NYC Department of Education (2013). NYC department of education social media guidelines. Retrieved from http://schools.nyc.gov/NR/rdonlyres/BCF47CED604B-4FDD-B752-DC2D81504478/0/SMG_FINAL_20130415.pdf.

Olson, J., Clough, M., \& Penning, K. (2009). Prospective elementary teachers gone wild? An analysis of Facebook self-portrayals and expected dispositions of preservice elementary teachers. Contemporary Issues in Technology and Teacher Education, 9(4), 443-475. Retrieved from http://www.citejournal.org/vol9/iss4/ general/article1.cfm.

Oolo, E., \& Siibak, A. (2013). Performing for one's imagined audience: Social steganography and other privacy strategies of Estonian teens on networked publics. Cyberpsychology: Journal of Psychosocial Research on Cyberspace, 7(1). Retrieved from www.cyberpsychology.eu/view.php? cisloclanku=2013011501\&article=7.

Patton, M. Q. (2002). Qualitative research \& evaluation methods (3rd ed.). London: Sage.

Poom-Valickis, K., \& Löfström, E. (2014). Pikiuuring õpetajaks õppijate professionaalse identiteedi kujunemisest. Eesti Haridusteaduste Ajakiri, 2(1), 241-271. http://dx.doi.org/10.12697/eha.2014.2.1.10

Prensky, M. (2001). Digital natives, digital immigrants. On the Horizon, 9(5), 1-6. Retrieved from http://www.marcprensky.com/writing/Prensky\%20-\%20 Digital\%20Natives,\%20Digital\%20Immigrants\%20-\%20Part1.pdf. http://dx.doi.org/10.1108/10748120110424816

Rooste, K. (2013). Algklassiõpetajate ja -ópilaste suhtlustrendid Facebookis: õpetajate kogemused (magistritöö). Tartu Ülikool, Tartu. Külastatud aadressil http://dspace. utlib.ee/dspace/bitstream/handle/10062/31061/rooste_k2dli.pdf?sequence=1.

Russo, C. J., Squelch, J., \& Varnham, S. (2010). Teachers and social networking sites: Think before you post. Public Space: The Journal of Law and Social Justice, 5(5), $1-15$.

Shih, C. (2011). The Facebook era: Tapping online social networks to market, sell, and innovate (2nd ed.). New Jersey: Prentice Hall.

Siibak, A., \& Vinter, K. (2010). Making sense of the virtual world for young children: Estonian pre-school teachers' experiences and perceptions. Journal of Virtual Worlds Research, 3(2), 3-27. Retrieved from http://journals.tdl.org/jvwr/index.php/jvwr/article/view/1892/1161.

Tapscott, D. (1998). Growing up digital: The rise of the net generation. New York: McGraw-Hill. 
Vadrevu, S. (2011). Teacher identity and selective strategies for mediating interactions with students on Facebook. Paper presented at the annual meeting of the International Communication Association. Boston, USA.

Westin, A. (1968). Privacy and freedom. New York: Atheneum.

Williams, R. W. (2012). Digital immigrant teacher perceptions of social media as it influences the affective and cognitive development of students: A phenomenological study (Doctoral dissertation). Liberty University, Lynchburg, USA. Retrieved from http://digitalcommons.liberty.edu/cgi/viewcontent.cgi?article=1613\&contex $\mathrm{t}=$ doctoral. 


\title{
Teacher-student interaction on social networking sites: teachers' perceptions and experiences
}

\author{
Sandra Räim ${ }^{\text {a1 }}$, Andra Siibak ${ }^{\mathrm{a}}$ \\ a University of Tartu, Institute of Social Sciences
}

\begin{abstract}
Summary
Due to the „context collapse” (Marwick \& boyd, 2010) on networked publics, students and teachers have suddenly gained access to each other's information, which previously was considered private.

Although there has been a heated debate in the USA about whether it is ethical and legal for teachers to interact with their students on social media (Lehrer, 2011; Miller, 2011), the topic has gained much less attention in a European context. In comparison to many school districts and states in the US which have passed policies and regulations designed to limit teacherstudent interactions on social media (Lehrer, 2011), similar student-teacher communication bans have only been passed in Rhineland-Palatinate and Schleswig-Holstein states in Germany (German state bans, 2013). In Estonia, there has been no public discussion on the topic, nor have the schools developed any rules or recommendations for the teachers. As teachers are historically seen as mentors and role models for the youth (Miller, 2011), we believe it is crucial to gain additional knowledge about teachers' perceptions about the issue as well as their experiences and opinions about "friending” one's students and thereby having a chance to monitor their information sharing-practices.

The aim of the present article is to give an overview of a small group of Estonian teacher's perceptions and experiences about teacher-student interaction and content creation on social networking sites (SNS). In springsummer 2013, four focus-group interviews with teachers $(\mathrm{N}=21)$ from highschools in Estonia were conducted to study what kind of differences have the teachers noticed when comparing online content creation practices of their students and themselves, and also so as to find out on which occasions and how have the teachers decided to react on their students' posts. We also explored how a teacher-student "friendship” is formed and if the teachers feel a need for social media guidelines.
\end{abstract}

1 Institute of Social Sciences, Faculty of Social Sciences and Education, University of Tartu Lossi 36, 51003 Tartu; sandra.raim@ut.ee 
In the theoretical background of the manuscript, we will argue that in today's technology saturated society ICTs are strongly immersed to the culture, and help to generate differences between generations - between the 'digital natives', i.e. youth who have grown up in the area of rapid changes in digital technologies and the 'digital immigrants' i.e. members of the older generations who do not have that close relationship with digital technologies (Prensky, 2001). Relying on the findings of Ellison and boyd (2013), we then describe the main changes in communication that occur in networked publics. We will introduce the concept of social convergence (boyd, 2008) and describe that in addition to the "ideal audience" i.e. one's closest friends and peers, one's posts on SNS may also be available to "nightmare readers", e.g. one's teachers, parents and bosses (Marwick \& boyd, 2010). Studies suggest that young people do not seem to grasp the size and diversity of the actual audience SNS and fail to recognize the importance of contextual integrity (Nissenbaum, 2004) while composing their posts. We end the theoretical background by providing both positive and negative examples of teachers' SNS practices.

In the method and data section, we will describe the ways of data collection and analysis in greater detail. Empirical data was gathered by structured focus group interviews. The method was preferred so as to create a situation more similar to real life interaction (Patton, 2002). By stimulating group dynamics, we also hoped to identify the opinions our participants shared (ibid.). For data analysis, conventional qualitative content analysis was used.

Our strategic sample was made up of 21 high-school teachers from four schools. All of the teachers had to have a Facebook account and needed to teach in high-school. We also aimed to have at least one class teacher in every focus group, because they tend to have a closer relationship with their students. Our final sample comprised of 3 men and 18 women who were between the ages of 23-51. The focus-groups took place in spring-summer 2013 and lasted from one to two hours.

The findings of our study suggest that teachers believe the SNS user practices and content creation habits of teachers and students to be very different. According to the interviewed teachers the main differences between the generations had to do with the nature of the information shared and the audience amongst whom it was shared. Teachers in all our focus groups felt that students do not realize the actual size of the audience on SNS. Such misperception was considered to be typical to the present day youth and hence also a sign that young people have not fully grasped the idea of social convergence (boyd, 2008) on networked publics and the need for contextual integrity (Nissenbaum, 2004). 
Furthermore, according to the teachers, students often tended to post inappropriate content on their profiles. Teachers claimed that in case they come across posts which contain messages of bullying or promotion of illegal activities, or notice photos which are either too revealing or about parties and alcohol, they feel the need to address the issue. The need to intervene was explained by the role of a teacher - all of the teachers in our focus groups agreed that the teachers should stay true to their traditional role of a mentor and role model both offline and online. Having a private face-to-face conversation or sending a private message through Facebook were considered to be the most effective ways for getting through to students on such occasions. Still, some of the teachers also felt that since Facebook is a public site, it is appropriate for teachers to voice their opinions by writing a public comment. Compiling such a public response was seen as a way of teaching the students the meaning of public space, however, on such occasions the possible negative effect on a student was clearly not thought through. Teachers also believed too active posting to be inappropriate, however, in such a case they did not consider it important or necessary to intervene.

In general, the teachers in our sample perceived the practices of their students to be typical of present day 'digital natives' (Prensky, 2001). They opposed such behaviour with their own user practices, which in contrast, were claimed to be thought-through and rather minimal. The teachers said to value their privacy and hence the majority of them avoided making posts and uploading photos that could reveal something private e.g. information about their family, relationships, etc.

The teachers in our sample neither had any deep ethical or moral concerns about „friending” their students on Facebook, nor felt that there was a need to regulate student-teacher relationships on networked publics. Still, in order to become "friends" with one's teacher on Facebook, the student had to first meet a certain criteria. For instance, the student needed to be personally known to the teacher either by attending the class they had taught or they had got acquainted through some after-school activity. Older students and the one's whose content creation practices were considered to be more adult-like also had a bigger chance of the teacher accepting their friend-request. The teachers also believed that such a "friendship" should generally be initiated by the student.

Regardless the fact that our study participants did not feel a need for any guidelines, or recommendations on the topic, we believe that having some general guidelines to regulate teacher-student communication on SNS would actually benefit both parties.

Keywords: social networking sites, teacher-student „friendship” on social networking sites, privacy, generational difference, teacher's role 